\title{
AKTIVITAS HUMAS DPRD KOTA PALU SEBAGAI MEDIATOR ASPIRASI MASYARAKAT
}

\author{
Alem Febri Sonni ${ }^{1}$, Ratmila Riandani ${ }^{1}$, Andi Alimuddin Unde ${ }^{\mathbf{1}}$, Abdul Gafar ${ }^{1}$ \\ ${ }^{I}$ Fakultas Ilmu Sosial dan Ilmu politik, Universitas Hasanuddin \\ "Email: afsonni@gmail.com
}

\begin{abstract}
The aim of this study were (1) to find out how the public relations activities of Palu City Council in running the function as mediator aspirations of the community, and (2) to find out what are the inhibitors and supporter of public relations activities in its function as mediator aspirations of the people. This type of research is descriptive qualitative, that describe, explain and define about the object under study is based on interviews and observations obtained in a study of public relations officials and officials of Palu City Council. The results of this study indicate that the activity of the Public Relations Council of Palu in its function as a mediator by way of mediating the public officials of Parliament linked to the existing problems and the other functions of public relations City Council Palu also conducts publicity activities The factors supporting and inhibiting Public Relations Activities Palu City Council as a mediator aspirations of the people which is understanding public relations officer with their function and of course a good cooperation between members of the public relations is very helpful in fulfilled public relations function. While the limiting factor is the lack of human resources (HR) and facilities that support the activities of PR in publish and disseminate information.
\end{abstract}

Keywords: Public Relation; Aspiration; Mediator

\begin{abstract}
ABSTRAK
Tujuan dari penelitian ini adalah (1) untuk mengetahui bagaimana aktivitas humas DPRD Kota Palu dala menjalankan fungsinya sebagai mediator aspirasi masyarakat, dan (2) untuk mengetahui apa saja yang menjadi pendukung dang penghambat aktivitas humas dalam menjalankan fungsinya sebagai mediator aspirasi masyarakat. Tipe penelitian yang digunakan adalah deskriptif kualitatif, yaitu menggambarkan, memaparkan serta menjelaskan mengenai objek yang diteliti berdasarkan wawancara serta observasi yang diperoleh dalam penelitian terhadap pejabat humas dan pejabat DPRD Kota Palu. Hasil penelitian ini menunjukkan bahwa aktivitas Humas DPRD Kota Palu dalam menjalankan fungsinya sebagai mediator dengan cara memediasi masyarakat dengan pejabat DPRD terkait dengan permasalahan yang ada. Adapun faktor pendukung dan penghambat Aktivitas Humas DPRD Kota Palu sebagai mediator aspirasi masyarakat yaitu pemahaman petugas humas akan fungsinya dan tentunya kerjasama yang baik antara anggota humas sangat membantu dalam terlaksanakannya fungsi humas. Sedangkan yang menjadi faktor penghambat yaitu minimnya sumber daya manusia (SDM) dan fasilitas yang mendukung aktivitas Humas dalam mepublikasikan maupun menyebarluaskan informasi.
\end{abstract}

Kata Kunci: Humas; Aspirasi; Mediator

Submisi: 23 Juli 2021

KINESIK Vol. 8 No. 2 (2021) | 146 


\section{Pendahuluan}

Lembaga Dewan Perwakilan Rakyat Daerah (DPRD) mempunyai alat kelengkapan yang terdiri atas pimpinan, badan musyawarah, komisi, badan legislasi daerah, badan anggaran, badan kehormatan, dan alat kelengkapan lainyang dibentuk oleh rapat paripurna.

Untuk mendukung kelancaran pelaksanaan tugas DPRD, dibentuk sekretariat DPRD yang personelnya terdiri atas pegawai negeri sipil. Sekretariat DPRD adalah penyelenggara administrasi kesekretariatan, administrasi keuangan, pendukung pelaksanaan tugas dan fungsi DPRD dan bertugas menyediakan serta mengoordinasikan tenaga ahli yang diperlukan oleh DPRD sesuai dengan kemampuan keuangan daerah. Sekretariat DPRD dipimpin seorang sekretaris DPRD yang diangkat oleh kepala daerah atas usul pimpinan DPRD. Sekretaris DPRD secara teknis operasional berada di bawah dan bertanggung jawab kepada pimpinan DPRD dan secara administratif bertanggung jawab kepada kepaladaerah melalui sekretaris daerah.

Pada sekretariat DPRD Kota Palu dibentuk salah satu sub bagian yaitu Hubungan Masyarakat (Humas). Aktivitas Humas DPRD Kota Palu banyak berhubungan dengan masyarakat, antara lain humas menjembatani aspirasi masyarakat ke komisi terkait.

\section{Disamping}

bertugas

menyelenggarakan dan mengkoordinasikan lalu lintas arus informasi ke dalam dan ke luar, humas juga berfungsi sebagai penyaring atau filter dari komunikasi timbal balik dengan tujuan untuk menciptakan dan membina stabilitas sosial.

Pada dasarnya, humas adalah kegiatan yang bertujuan memperoleh goodwill, kepercayaan, saling adanya pengertian dan citra yang baik dari publik atau masyarakat pada umumnya.

Humas sebagai komunikator mempunyai fungsi ganda yaitu keluar memberikan informasi kepada khalayak dan kedalam menyerap reaksi dari khalayak.
Organisasi atau lembaga mempunyai tujuan dan berkehendak untuk mencapai tujuan itu (Widjaja, 2002: 6)

Kegiatan hubungan masyarakat (humas) pada hakikatnya adalah kegiatan komunikasi. Ciri hakiki dari komunikasi dalam humas adalah komunikasi yang bersifat dua arah timbal balik (Two Ways Traffic Communication). Komunikasi yang bersifat timbal balik ini sangat penting dan mutlak harus ada dalam kegiatan humas, dan terciptanya Feedback merupakan prinsip pokok dalam humas.

Aspirasi dari masyarakat kepada Dewan harus dapat dikelola dengan baik sesuai dengan mekanisme yang ada. Masyarakat yang akan menyampaikan aspirasi kepada Dewan selalu ingin dapat bertemu dan mendapat tanggapan secara langsung dari Dewan, namun terkadang mereka tidak memperhatikan prosedur dan birokrasi yang berlaku di Sekretariat DPRD Kota Palu mengenai tata cara atau mekanisme penyampaian aspirasi masyarakat kepada Dewan.

Menjadi salah satu tugas humas di Sekretariat DPRD Kota Palu untuk dapat melayani aspirasi dari masyarakat dengan baik. Agar aspirasi masyarakat ini tepat pada sasaran dan bidangnya maka harus ditangani dengan strategi kehumasan secara efektif. Ketika aspirasi masyarakat disampaikan kepada dewan, masyarakat menginginkan aspirasi tersebut bisa langsung ditampung, ditanggapi, dan segera ditindaklanjuti sesuai dengan permasalahan yang ada, namun keinginan masyarakat tersebut tidak selamanya dapat terpenuhi atau dengan kata lain tanggapan dari dewan dinilai tidak memuaskan dan tidak memenuhi aspirasi.

\section{Hubungan Masyarakat}

Fraser P. Seitel, Senior Vice President dan Director of Public Affairs The Chase Manhattan Bank, dalam bukunya The Practice of Public Relations mengemukakan pada tahun 1975 Yayasan Pendidikan dan Penelitian Humas telah melibatkan 65 pimpinan Humas turut serta dalam suatu penelitian yang menganalisis 472 definisi 
yang berminat dan merangkumnya dalam 88 kata, yaitu humas merupakan fungsi manajemen yang membantu menciptakan dan saling memelihara alur komunikasi, pengertian, dukungan, serta kerjasama suatu organisasi/perusahaan dengan publiknya dan ikut terlibat dalam menanggani masalah - masalah atau isu - isu manajemen. Humas membantu manajemen dalam menyampaikan informasi dan tanggap terhadap opini masyarakat. Humas secara efektif membantu manajemen memantau berbagai perubahan (Sietel, 1992: 8).

\section{Aspirasi Masyarakat}

Aspirasi masyarakat juga bisa di artikan sebagai pendapat atau opini masyarakat yang berarti berpikir atau menduga dan pilihan atau harapan. Sedangkan kata masyarakat mempunyai arti, "milik orang banyak atau bersama". Dengan demikian, hubungan antara keduakata itu, menyangkut hal seperti dugaan, perkiraan, harapan dan pilihan yang dilakukan orang banyak.

Definisi aspirasi masyarakat itu berhubungan erat dengan opini publik sikap manusia yaitu sikap secara pribadi maupun sebagai anggota suatu kelompok. lebih jauh mengemukakan bahwa yang membentuk aspirasi masyarakat adalah sikap pribadi seseorang ataupun sikap kelompoknya.

Komunikasi persuasi bila dihubungkan dengan aspirasi masyarakat, aspirasi masyarakat itu sifatnya akan tetap latent (terpendam) dan baru memperlihatkan sifatnya yang aktif apabila issue itu timbul dalam sesuatu kelompok atau lingkungan. Suatu issue itu timbul kalau terdapat konflik, kegelisahan atau frustasi.

Aspirasi masyarakat adalah kumpulan pendapat individu terhadap masalah tertentu yang mempengaruhi suatu kelompok orang-orang (masyarakat). Pendapat lain menyebutkan bahwa aspirasi masyarakatmewakili suatu kesepakatan, dan kesepakatan dimulai dengan sikap orangorang terhadap isu yang masih tanda tanya. Mencoba untuk mempengaruhi suatu sikap yang dimiliki individu bagaimana tanggapan terhadap suatu pokok permasalahan yang dihadapi merupakan suatu fokus utama dari kegiatan Public Relations.

Dengan munculnya aspirasi masyarakat bisa dicermati, siapakah yang memiliki keterbukaan itu dan sejauh mana keterbukaan tersebut bisa tampak pada kualitas aspirasi masyarakat itu. Aspirasi masyarakat tersebut akan menunjukkan kualitas dan akan mempunyai arti untuk mengadakan perbaikan, sekaligus perkembangan organisasi.

\section{Standar Tata Kelola Kehumasan Pemerintah}

Tata kelola kehumasan merupakan proses yang meliputi kegiatan analisis situasi (pengumpulan data dan fakta), strategi (perencanaan dan program), implementasi (tindakan dan komunikasi), evaluasi (pengukuran hasil), dengan tetap berpegang kepada komitmen, etika kehumasan, dan praktik-praktik terbaik.

Undang-undang Nomor 14 Tahun 2008 Pasal 7 tentang keterbukaan informasi publik, mengamanatkan bahwa setiap badan publik wajib membangun dan mengembangkan sistem informasi dan dokumentasi untuk mengelola informasi publik secara baik dan efesien sehingga layanan informasi dapat memberikan akses dengan mudah. Bahkan, setiap badan publik perlu melakukan pengelolaan informasi dan dokumentasi yang dapat menjamin penyediaan informasi yang mudah, cermat, cepat, dan akurat. Pengelolaan informasi dan dokumentasi dimaksud mengacu Peraturan Pemerintah Republik Indonesia Nomor 61 Tahun 2010 tentang Pelaksanaan Undang-Undang Nomor 14 Tahun 2008 tentang Keterbukaan Informasi Publik.

Pedoman Umum Tata Kelola Kehumasan di Lingkungan Instansi Pemerintah merupakan panduan dan acuan pelaksanaan pengelolaan kehumasan di lingkungan instansi pemerintah. Pedoman umum ini akan menjadi sumber rujukan dalam pembuatan petunjuk pelaksanaan dan 
petunjuk teknis aktivitas pengelolaan kehumasan di instansi masing-masing. Pedoman ini dibuat bertujuan menciptakan pengelolaan kehumasan di lingkungan instansi pemerintah pusat dan daerah secara efektif dan efesien, sesuai dengan prinsipprinsip tata kelola pemerintahan yang baik. Adapun visi humas pemerintah adalah terciptanya pengelolaan kehumasan (kelembagaan, ketatalaksanaan, dan SDM) yang proposional, profesional, efektif, dan efesien dalam mendukung penerapan prinsip-prinsip tata kepemerintahan yang baik.

\section{Fungsi Mediator}

Salah satu fungsi dari humas pemerintahan yaitu sebagai mediator yang berhungan langsung antara organisasi / instansi dan publiknya. (Ruslan, 2008: 110) menyatakan fungsi pokok Humas Pemerintah yaitu menjadi komunikator sekaligus mediator yang proaktif dalam upaya menjembatani kepentingan instansi pemerintah di satu pihak dan menampung aspirasi / atau opini publik (masyarakat) di lain pihak.

Sebagai mediator humas sangat berkaitan dengan aktivitas komunikasi karena komunikasi merupakan unsur utama yang terkandung di dalamnya. Komunikasi itu sendiri menurut Raymond Ross (Effendy, 2000) komunikasi adalah suatu proses menyortir, memilih dan mengirimkan simbol-simbol sedemikian rupa sehingga membantu pendengar membangkitkan makna atau respon dari pikirannya yang serupa dengan yang dimaksudkan komunikator.

Dalam hal ini jika dikaitkan dengan teori diatas maka antara humas dan publiknya yang terlibat dalam komunikasi harus terdapat kesamaan arti atau magna, sebisa mungkin humas melakukan hubungan komunkasi secara timbal balik, baik langsung maupun tidak langsung guna sebagai cara untuk mencapai hubungan yang efektif dengan publik.

\section{Model Humas}

Dalam humas, terdapat model yang menentukan sebuah pesan yang akan disampaikan kepada publik seperti yang dikemukakan James E. Grunig dan Todd Hunt empat model humas yang asli adalah Model Agen Pemberitaan (Press Agent / Publicity Model), Model Informasi Publik (Public Information Model), Model Asimetris Dua Arah (Two-way Asymmetrical Model), dan Model Simetris dua Arah (Two-way Symmetric Model). Tiga model pertama mereflesikan sebuah praktik Public Relationsyang berusaha mencapai tujuan organisasi melalui persusasi. Kemudian model keempat berfokus pada usaha menyeimbangkan kepentingan pribadi dengan kepentingan publik atau kelompok lainnya.

\section{Konseptualisasi Penelitian}

Penelitian ini dilakukan di Kantor Dewan Perwakilan Rakyat Daerah Kota Palu, Jalan Dr. Moh. Hatta No. 14 Palu, Selawesi Tengah.

Tipe penelitian yang digunakan adalah dekskriptif kualitatif yaitu memberikan gambaran secara cermat dan faktual yaitu penulis menggambarkan / melukiskan keadaan objek penelitian berdasarkan fakta yang ada mengenai peranan Humas DPRD kota Palu.

Penelitian diawali dengan penentuan fokus penelitian berupa rumusan penelitian yang dilanjutkan pengolahan data, adapun teknik pengumpulan data yang digunakan oleh penulis adalah melalui :

a. Data dalam penelitian ini terdiri dari data primer dan data sekunder, oleh karena penelitian ini menggunakan metode kualitatif, maka teknik pengumpulan data yang dilakukan adalah melakukan wawancara mendalam, observasi (pengamatan).

b. Penelitian pustaka, dengan mengkaji dan mempelajari literature yang berhubungan dengan permasalahan untuk mendukung asumsi sebagai 
landasan teori bagi persoalan yang dibahas dalam penelitian.

c. Informan, Berdasarkan metode penelitian deskriptif kualitatif, maka informan ditentukan dengan cara purposive sampling, yaitu teknik pemilihan informan berdasarkan kriteria-kriteria tertentu yang sesuai dengan tujuan penelitian (Kriyantono, 2006: 158)

Reduksi data diambil dari catatan hasil lapangan berupa wawancara dan kajian pustaka berupa arsip, tulisan maupun dokumen terkait objek penelitian. Hasil pengumpulan data di lapangan dan hasil wawancara yang diperoleh tersebut kemudian dianalisis dengan kajian analisis yang telah ditentukan.

Penyajian data kemudian diambil dari penarikan kesimpulan setelah proses penentuan fokus data yang sudah diperpendek dan dipertegas dalam menjelaskan hasil penelitian.

\section{Hasil Penelitian}

\section{Aktivitas Humas DPRD Kota Palu Sebagai Mediator Aspirasi Masyarakat}

Hubungan masyarakat atau yang disebut juga Public Relations merupakan salah satu bagian terpenting dan tidak dapat terpisah dari sistem manajemen dalam suatu organisasi. Hal ini dikarenakan, Humas dalam upaya menyelenggarakan komunikasi timbal balik antara organisasi dengan publiknya tersebut dapat menentukan sukses tidaknya usaha organisasi dalam upaya meraih citra positif. Dengan kata lain, Humas berperan sebagai fasilitator dalam penyampaian informasi-informasi mengenai keadaan suatu organisasi yang dianggap penting dan patut diketahui para pihak stakeholder atau publik.

Dalam menjalankan aktivitasnya humas di Sekretariat DPRD Kota Palu sebenarnya juga telah mengupayakan pola kerja yang dapat memaksimalkan kinerja humas, diantaranya dengan melakukan pembagian tugas dan fungsi untuk masingmasing stafnya.
"Sebagai staf saya memiliki tugas dan fungsi tersendiri seperti bertanggung jawab membuat Notulen / Laporan hasil rapat. Setiap staf humas disini memiliki tupoksinya masing-masing."

Pembagian tugas dan fungsi staf ini tentunya dimaksudkan untuk memaksimalkan kinerja humas sehingga masingmasing staf bisa fokus pada tugas dan fungsinya masing-masing. Hal ini juga memungkinkan kinerja humas menjadi lebih maksimal, karena masing - masing staf tidak akan bingung dengan apa yang akan mereka kerjakan.

Hal yang sama juga disampaikan oleh staf humas lainnya menyangkut pembagian tugas untuk masing - masing para staf.

"Saya bertugas mengelola administrasi bagian humas dan penyerapan aspirasi juga membuat pertanggung jawaban per-Triwulan Kegiatan humas"

Hal ini menegaskan bahwa memang humas melakukan pembagian kerja untuk para staf atau anggotanya dengan tujuan memaksimalkan kinerja. Hal ini juga diakui oleh Kepala Bagian Humas DPRD Kota Palu Agnan, S.Sos M.Ap.

"Setelah saya membagi uraian tugas, saya rasa itu sangat membantu karena staf akan mengerjakan tugas-tugasnya sesuai dengan tupoksi tersebut."

Pembagian tugas dan fungsi bagi masing-masing staf sangat membantu staf dalam mengenali pekerjaannya.

Penulis akan memasuki penjabaran mengenai aktivitas humas DPRD Kota Palu sebagai mediator. Seperti yang tertera pada penjelasan sebelumnya bahwa fungsi mediator bersifat ke dalam dan keluar. Fungsi humas sebagai mediator terlihat jika ada para aspirator yang datang ke kantor DPRD Kota Palu.

Humas di Sekretariat DPRD Kota Palu telah mencoba menjalankan tugas dan fungsi sebagaimana mestinya diantaranya dengan menjembatani para aspirator. 


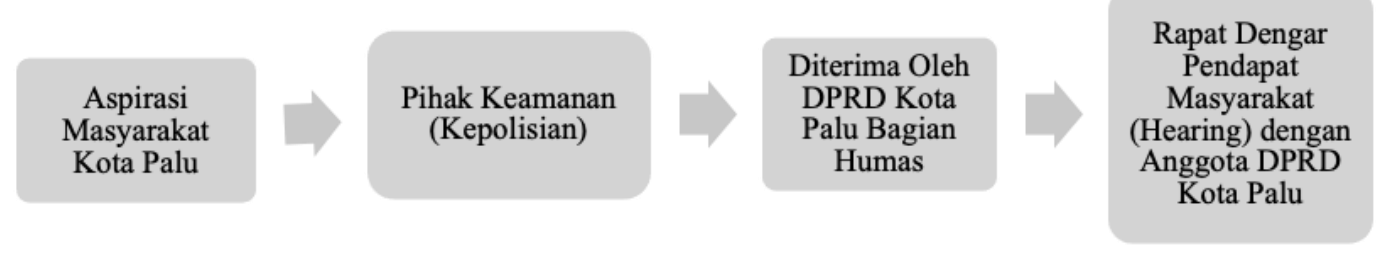

Gambar 1. Bagan Penerimaan Aspirasi Secara Spontanitas

"Humas bertugas membantu menjembatani angggota dewan dengan masyarakat dalam hal penyampaian aspirasi. Kamilah yang akan memfasilitasi para aspirator ke dewan hingga rapat dengar pendapat."

Humas bertugas membantu masyarakat yang ingin menyampaikan aspirasinya kepada dewan hinggan sampai pada dilakukannya rapat dengar pendapat dengan dewan, komisi maupun instansi terkait.

Aspirasi biasanya datang dalam bentuk demonstrasi dimana pembawa aspirasi datang langsung ke Kantor DPRD Kota Palu. Hal ini tentunya tidak terasa asing lagi bagi para anggota Dewan Perwakilan Rakyat Daerah ( DPRD ) karena ini sudah biasa terjadi. Dalam keadaan seperti ini humaslah yang akan turun langsung atau menerima aspirator yang datang tersebut.

"Aspirasi yang masuk ada dua jenis yaitu bersifat spontanitas (demonstrasi) tanpa melalui dan secara menyurat atau resmi yang melalui daripada kapolres. Jika ada para demonstran yang datang ke halaman kantor maka sesuai dengan permintaan pemeritah akan diterima oleh dewan secara mereka berorasi. untuk didiskusikan apa maksud dan tujuannya lalu kemudian kami hubungkan dengan dewan / komisi terkait untuk melakukan rapat dengar pendapat/Hearing. Ketentuan-ketentuan dalam pelayanan untuk penyampaian aspirasi itu sesuai dengan undangundang keterbukaan informasi publik."
Dalam menangani aspirasi masyarakat menurut humas mereka telah melakukan prosedur penanganan dengan dua bentuk yaitu spontanitas dan jalur koordinasi. Hal ini dilengkapi dengan adanya bagan inovasi pelayanan publik humas Sekretariat Dewan Perwakilan Rakyat Daerah Kota Palu yang penulis dapatkan dari bagian humas.

a. Spontanitas (demonstrasi), pada bagian ini masyarakat yang datang berdemonstrasi untuk menyampaikan aspirasi didampingi oleh kepolisian dan diterima oleh Sekretariat DPRD Kota Palu Bagian Humas dan langsung melakukan dengar pendapat dengan anggota DPRD Kota Palu. Setiap demonstran yang datang ke kantor DPRD ini selalu didampingi oleh aparat keamanan. Tambahan dari Agnan selaku Kasubag humas bahwa:

"Untuk demonstran yang jumlahnya mencapai 50 orang, akan kami mintakan Koordinator lapangan atau ketua tim sebagai perwakilan untuk bertemu langsung dengan dewan menyampaikan apa yang menjadi keinginan mereka sedangkan kalau jumlahnya 100 orang kami terima dihalaman kantor dalam bentuk mereka berorasi."

b. Masyarakat yang ingin menyampaikan aspirasi mereka harus melalui proses, pertama yaitu melalui humas untuk dipertanyakan maksud dan tujuan kedatangan. kemudian dilakukan Hearing atau dengar pendapat dengan mengundang instansi terkait. 


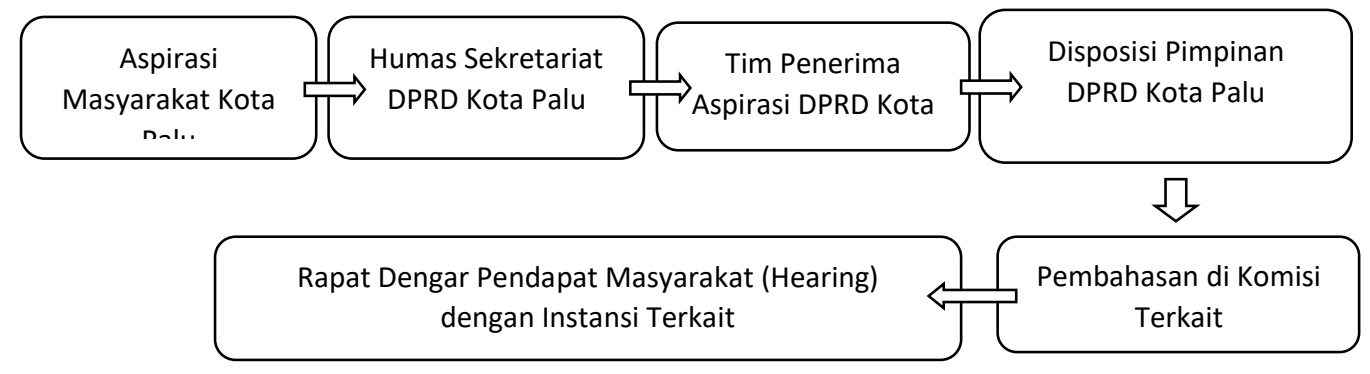

Gambar 1. Bagan Penerimaan Aspirasi Secara Terstruktur

Terkait dengan data yang penulis dapatkan diatas kemudian penulis lanjut pada hal yang terkait dengan kadang terjadinya penyampaian aspirasi yang masuk ke kantor DPRD Kota Palu tanpa melalui seperti prosedur yang telah dibuat maupun ditetapkan di kantor DPRD Kota palu tersebut melainkan langsung kepada anggota dewan.

"Kalau ada penyampai aspirasi yang masuk langsung pada komisi tertentu itu akan kami kembalikan pada prosedurnya. Biasanya itu terjadi karena adanya kedekatan hubungan penyampai aspirasi dengan dewan pada komisi tersebut."

Hal ini kemudian ditanggapi juga oleh Kepala Bagian Hubungan Masyarakat DPRD Kota Palu sebagai berikut :

"Untuk penyampaian aspirasi itu kita sudah buatkan prosedurnya dan itu kita publikasikan pada media massa maupun pada website kami tapi terkadang masih ada para aspirator yang tidak memahami atau mungkin tidak tahu kalau prosedur tersebut sehingga langsung membawa aspirasi pada dewan tanpa melalui kami petugas humas."

Dari jawaban diatas sebenarnya humas telah berusaha melakukan publikasi kepada masyarakat mengenai prosedur penyampaian aspirasi untuk di DPRD kota palu hanya saja pada persoalan penyampaian aspirasi yang langsung kepada dewan itu dikarenakan para aspirator/penyampai aspirasi tidak memahami atau bahkan mungkin tidak tahu akan adanya prosedur penyampaian aspirasi tersebut.

Seperti sebagaimana harusnya humas mampu nenangani aspirasi masyarakat dan mampu memberi informasi kepada masyarakat mengenai kebijakan-kebijakan maupun mengenai kegiatan atau aktivitas instansi yang bersangkutan, Rosida Thalib sebagai Sekretaris Dewan Perwakilan Rakyat Daerah (DPRD) Kota Palu mengungkapkan bahwa :

"Di sekretariat ini kami telah menyiapkan sub. bagian khusus yang menjadi penanggungjawab dalam menyampaikan informasi dan untuk menerima aspirasi masyarakat."

Informasi ini menunjukan dari segi aspek pelaksanaan sudah baik, karena di Sekretariat DPRD Kota Palu telah menyiapkan sub. bagian khusus yang menangani aspirasi publik/masyarakat yang berhubungan dengan pembuatan kebijakankebijakan publik di kota palu.

Mengenai tugas dan fungsi Hubungan Masyarakat itu sendiri, penulis mencoba menggali apa tupoksi yang ada senantiasa berjalan sesuai ketentuanya.

"Kami sebagai humas memediasi anggota dewan dan masyarakat. Dalam hal ini seperti jika ada aspirator telah menyampaikan aspirasinya kepada dewan maka kita memediasi tergantung daripada kasusnya kemudian kita temui komisi yang bersangkutan, nanti pada saat sudah diterima maka kita akan menghubungi daripada 
mitranya dengan pemerintah kota. Setelah aspirasi diterima hasilnya akan kami buatkan notulen."

Mengenai pemahaman pelaksana, Rosida Thalib mengungkapkan bahwa ;

"Staf di sub. bagian hubungan masyarakat dan penyerapan aspirasi masyarakat sudah memahami apa tugas dan fungsi mereka diposisi tersebut, dalam melaksanakan tugas staf di humas juga sudah optimal dalam menerima aspirasi masyarakat di DPRD Kota Palu."

Hal ini menunjukan bahwa pemahaman pelaksanaan humas terhadap tugasnya sudah baik, karena mereka sudah bisa melayani masyarakat dengan baik, baik masyarakat yang datang untuk kepentingan menyampaikan aspirasi maupun yang melakukan audensi kepada pimpinan.

Daenta S.Sos sebagai Staf Bagian Hubungan Masyarakat DPRD Kota Palu mengungkapkan :

"Kami dibagian humas dewan selama ini telah menyampaikan kepada pihak-pihak yang berkepentingan dengan informasi publik yang bisa diakses oleh masyarakat, bisa mengambil dengan kami. Kami juga telah bekerjasama dengan media untuk menyampaikan ke masyarakat tentang kinerja anggota dewan."

Dari wawancara tersebut, menggambarkan bahwa bagian Hubungan Masyarakat telah memberikan informasi kepada pihak-pihak yang berkepentingan terhadap informasi publik, bisa berhubungan langsung dengan bagian Hubungan Masyarakat.

"Dibagian humas sekretariat dewan, setiap harinya berbagai instansi pemerintah dan swasta, kami layani untuk mendapatkan informasi yang mereka butuhkan. Memang sudah menjadi tugas dan fungsi kami untuk memfasilitasi aspirasi masyarakat dalam menyampaikan beberapa hal, baik masukan maupun tuntutan kepada para anggota dewan, maka itu menjadi tugas kami untuk meneruskan kepada unsur-unsur yang berkaitan dengan tuntutan masyarakat itu."

Ujaran tersebut, menggambarkan bahwa keterbukaan informasi telah dilakukan dengan baik oleh Hubungan Masyarakat Sekretariat Dewan Perwakilan Rakyat Daerah Kota Palu, dengan memberikan informasi yang publik butuhkan, baik kepada instansi pemerintah maupun instansi swasta.

Mengenai pemahaman pelaksana, Andi magga mengungkapkan bahwa :

"Pelayanan bagian hubungan masyarakat dan penyerapan aspirasi sudah baik, menandakan mereka memahamibetul apa tugas dan tanggungjawab mereka sebagai pengelolah informasi publik di Dewan Perwakilan Rakyat Daerah Kota Palu."

Hal ini menunjukan, bahwa pemahaman pelaksana dalam pelaksanaan kebijakan keterbukaan publik di Dewan Perwakilan Rakyat Daerah Kota Palu sudah baik, karena mereka sudah bisa melayani masyarakat dengan baik, baik masyarakat yang datang untuk kepentingan menyampaikan aspirasi maupun yang melakukan audensi kepada pimpinan.

Faktor-faktor yang Mendukung dan Menghambat Aktivitas Humas DPRD Kota Palu Sebagai Mediaotor Aspirasi Masyarakat

Untuk mengetahui apakah fungsi Hubungan Masyarakat Sebagai Mediator Aspirasi Masyarakat di Sekretariat Dewan Perwakilan Rakyat Daerah Kota Palu telah berjalan baik, dapat dilihat dibawah ini, yang dikutip dari pendapat informan yang bernama Muhammad Ikbal Andi Magga yang merupakan Ketua Dewan Perwakilan Rakyat Daerah (DPRD) Kota Palu, yang mengemukakan bahwa : 
"Dari segi Sumber Daya Manusia, pelaksanaan Hubungan Masyarakat Sebagai Mediator masih belum memadai, hanya ada 3 staf ditambah 1 orang Kepala Sub.Bagian, yang menangani arus aspirasi tentulah masih sangat kurang. Ditambah lagi dengan fasilitas yang seadanya, tidak adanya ruang khusus yang menjadi ruang aspirasi masyarakat, serta perangkat teknologi komunikasi yang belum bisa menjangkau masyarakat secara luas."

Sumber daya manusia dan non manusia dalam pelaksanaan penyerapan aspirasi Hubungan Masyarakat di Dewan Perwakilan Rakyat Daerah masih belum baik. Hal ini disebabkan dari jumlah staf yang menangani hubungan masyarakat dan penjaringan aspirasi hanya ada 4 orang, yang sangat minim untuk untuk bisa menampung aspirasi yang masuk. Ditambah lagi dengan fasilitas sarana yang masih belum mendukung penyebarluasan informasi yang luas ke masyarakat.

Hal senada juga disampaikan oleh Rosida Thalib, sebagai Sekretaris Dewan Perwakilan Rakyat Daerah (DPRD) Kota Palu, yang mengungkapkan bahwa :

"Kami di Sekretariat Dewan ini merasakan betul bahwa persoalan sumber daya manusia dan non manusia sudah menjadi kendala klasik disini, diantaranya kendala pada sarana dan prasarana yakni tidak tersedianya website sekretariat Dewan."

Hal ini menggambarkan bahwa pelaksanaan penyaluran aspirasi oleh Hubungan Masyarakat di Sekretariat Dewan Perwakilan Rakyat Daerah Kota Palu dari aspek sumber daya manusia dan non manusia belum optimal, karena masih mengalami hambatan pada ketidaksediaan sarana informasi yang bisa menambah daya dukung sekretariat dewan dalam melaksanakan tugas pokok dan fungsinya.

Informan lainnya dari Daenta sebagai Staf Bagian Hubungan Masyarakat
DPRD Kota Palu, yang menyebutkan bahwa :

"Kami yang menangani bagian kehumasan dan penjaringan aspirasi masyarakat ini hanya ada 4 orang, dengan banyaknya aktivitas kedewanan yang sangat berkaitan erat dengan hubungan masyarakat yang akan melakukan penyaluran aspirasi kepada para anggota dewan. Dari segi sarana kami masih kekurangan, hal ini dibuktikan bahwa sampai saat ini website yang bisa menyebarluaskan aktivitas maupun hasil - hasil keputusan anggota dewan belum dapat digunakan."

Masih terkait dengan fasilitas yang kurang memadai, Agnan selaku Kasubag humas menambahkan bahwa :

"Untuk sarana itu masih belum maksimal, kurangnya itu adalah kamera, audio visual dalam hal ini dimaksudkan sebagai alat dokumentasi kami. Dan untuk website pada tahun 2013 sampai 2015 itu masih ada, hanya saja sekarang sudah terputus dikarenakan kurangnya anggaran. Itu berawal dari awal tahun 2016 ini. koneksi internet juga tidak, ini juga terjadi mulai tahun 2016 sejak kewenangan pada saat itu diambil alih oleh pemerintah kota. Untuk sekarang kami memiliki 2 unit Komputer dan CCTV yang manfaatnya menjaga keamanan kantor dan untuk mengetahui apa saja yang terjadi di dalam kantor." Dari wawancara tersebut, menggambarkan bahwa sumber daya manusia dan non manusia/sarana prasarana dalam hal mendukung penyaluran aspirasi di Dewan Perwakilan Rakyat Daerah (DPRD) Kota Palu belum berjalan baik, hal ini disebabkan masih minimnya jumlah staf yang ada khusus yang menanggani hubungan masyarakat dalam penjaringan aspirasi masyarakat. Ditambah lagi dengan 
tidak adanya perangkat teknologi yang bisa mendukung pelaksanaannya.

\section{Analisis dan Interpretasi}

\section{Aktivitas Humas DPRD Kota Palu Sebagai Mediator Aspirasi Masyarakat}

Humas memiliki peranan penting dalam suatu manajemen untuk menunjang suatu instansi maupun perusahaan. Dimana humas mampu membentuk persepsi masyarakat terhadap instansi maupun perusahaan yang menauginya yang tentunya hal ini memberikan keuntungan bagi instansi tersebut. Selain itu melalui humas, pemerintah dapat menyampaikan apa - apa yang menjadi kebijakan, tindakan tindakan maupun informasi aktivitas aktivitas yang akan ataupun yang sedang dilaksanakan.

Seperti yang dikatakan oleh Ruslan bahwa keberadaan unit kehumasan di sebuah lembaga atau instansi milik pemerintah merupakan keharusan secara fungsional dan operasional dalam upaya menyebarluaskan atau mempublikasikan kegiatan atau aktivitas instansi bersangkutan yang ditujukan baik untuk hubungan masyarakat ke dalam maupun kepada masyarakat luar pada umumnya.

Dari pernyataan di atas penulis menjabarkan bahwa dengan adanya humas pada DPRD Kota Palu ini memudahkan masyarakat terutama dalam menyampaikan keluhan maupun masukan - masukan mereka terhadap pihak pemerintah, selain itu juga memudahkan masyarakat dalam memperoleh informasi pembangunan, kebijakan maupun tugas pemerintah. Sedangkan bagi pihak DPRD ini juga membantu untuk mengetahui informasi mengenai isu - isu yang ada di masyarakat dan tentunya juga untuk pembentukan citra mereka sebagai wakil rakyat.

Salah satu fungsi dari humas pemerintahan yaitu sebagai mediator yang berhubungan langsung antara organisasi / instansi dan publiknya. Seperti yang dikemukakan Ruslan bahwa fungsi pokok Humas Pemerintahan yaitu menjadi komunikator sekaligus mediator yang proaktif dalam upaya menjembatani kepentingan instansi pemerintah di satu pihak dan menampung aspirasi atau opini publik (masyarakat) di lain pihak.

Sebagai mediator humas sangat berkaitan dengan aktivitas komunikasi karena komunikasi merupakan unsur utama yang terkandung didalamnya. Dimana mediator adalah pihak ketiga yang bersikap netral yang memfasilitasi negosiasi solusi dengan menggunakan penalaran persuasi, menyodorkan alternative, atau semacamnya.

Fungsi humas sebagai mediator terlihat pada saat penulis melakukan penelitian terkait unjuk rasa yang pernah terjadi di kantor DPRD Kota Palu, penulis menjabarkan proses yang dilakukan Humas DPRD Kota Palu dalam menangani unjuk rasa masyarakat yaitu humas memediasi pihak dari pengunjuk rasa dengan pihak DPRD Kota Palu. Humas DPRD akan menampung aspirasi dari masyarakat dan memediasi pihak pengunjuk rasa (kor.lap) dengan pihak DPRD (tim khusus penerima aspirasi). Dalam hal ini Humas DPRD Kota Palu berperan sebagai mediator antara masyarakat dan DPRD.

Hal ini dijalankan humas DPRD Kota Palu dimana humas berkewajiban berhubungan langsung dengan masyarakat dalam menjalankan fungsinya sebagai penyerap aspirasi dan menjembatani masyarakat kepada dewan terkait dengan isi daripada aspirasi tersebut. Tidak hanya sampai di tahap itu saja, humas juga menganalisis daripada hasil rapat dengar pendapat antara pengunjuk rasa dan pihak pemerintah kemudian dibuatkan notulen, Hai ini tentunya tidak terlepas dari kerja sama yang terjalin antara staf humas dan sistem pembagian tupoksi utuk masingmasing staf yang membantu staf dalam mengenali tugasnya.

Pada ruang lingkupnya humas bertugas membina hubungan kedalam (internal) dan keluar (eksternal) memberikan informasi maupun pesan pesan sesuai dengan tujuan kepada masyarakat dan mentyerap aspirasi, opini dan reaksi masyarakat. 
Faktor-faktor yang Mendukung dan Menghambat Aktivitas Humas DPRD Kota Palu Sebagai Mediator Aspirasi Masyarakat

Dalam mengelola informasi humas pemerintah berperan membuka akses dan saluran komunikasi dua arah, antara instansi pemerintah dan publiknya, baik secara langsung maupun tidak langsung melalui sarana kehumasan.

Disebutkan pada undang-undang No.14 tahun 2008 pasal 7 bahwa setiap badan publik wajib membangun dan mengembangkan sistem informasi dan dokumentasi untuk mengelola informasi publik secara baik dan efesien sehingga layanan informasi dapat memberikan akses dengan mudah. Kemudian mengacu pada Peraturan Pemerintah Republik Indonesia mengenai pengelolaan informasi dan dokumentasi yang menjamin penyediaan informasi yang mudah, cermat, cepat dan akurat.

Dalam hal ini humas DPRD Kota Palu masih terhambat dikarenakan kurangnya ketersediaan alat kelengkapan yang sebenarnya dapat mendukung humas dalam menjalankan ativifitas menyebarluaskan informasi dan mendokumentasikan kegiatan-kegiatan untuk diarsipkan diantaranya kurangnya alat dokumentasi seperti kamera, alat perekam serta koneksi internet sebagai pendukung untuk mengakses daripada website.

seperti $\begin{gathered}\text { Pemanfaatan jaringan internet } \\ \text { dalam pengunaan website }\end{gathered}$ sebenarnya mampu menambah variasi dalam pengolahan pesan sehingga pesan atau informasinya tidak bersifat monoton. Hal ini juga tentunya akan menjadi pemenuhan kebutuhan masyarakat akan informasi dan memungkinkan adanya respon dari masyarakat yang tentunya itu akan menjadikan adanya hubungan timbal balik antara instansi dan publiknya. Dengan begitu masyarakat akan memiliki kecukupan informasi daripada instansi tersebut sehingga dapat mengurangi kesalahan persepsi masyarakat.
Selain itu Humas DPRD Kota Palu juga terkendala pada kurangnya staf pada bagian humas / sumber daya manusianya (SDM), ini dianggap tidak setara dengan tupoksi yang harus dilakukan dan dipertanggungjawabkan oleh pihak humas. Dimana kelengkapan sumber daya manusia (SDM) ini pastinya akan sangat membantu humas tentunya dalam menjalankan berbagai kegiatannya.

Penyampaian aspirasi di Kantor DPRD ini sendiri memiliki prosedur yang telah ditetapkan seperti yang telah dijelaskan pada pembahasan sebelumnya dimana aspirasi yang masuk ke kantor DPRD harus terlebih dahulu melalui humas untuk mengetahui maksud dan tujuan para aspirator kemudian dilanjutkan di disposisikan pada komisi dewan yang bersangkutan dengan perihal aspirasi tersebut lalu dilanjutkan lagi pada rapat dengar pendapat yang biasa juga disebut rapat Hearing. Namun dalam hal ini tidak jarang ada saja para aspirator yang tidak mengikuti daripada prosedur aspirasi tersebut dikarenakan belum pahamnya atau bahkan ketidaktahuan masyarakat maupun aspirator akan adanya prosedur tersebut padahal Humas DPRD Kota Palu sendiri telah melakukan publikasi prosedur tersebut melalui website maupun media massa. Karena itu maka penulis berasumsi bahwa publikasi prosedur tersebut kurang berhasil dan mungkin dibutuhkan peran yang lebih dari humas terkait hal ini seperti dengan mensosialisasikan prosedur penyampaian pesan ini secara langsung/tatap muka dengan masyarakat secara berulang.

\section{Simpulan}

Berdasarkan pembahasan yang telah penulis lakukan, maka dapat disimpulkan bahwa Humas DPRD Kota Palu dalam menjalankan aktivitasnya tidak jauh berbeda dengan humas pada umumnya yaitu membuat kliping dan pendokumentasian terkait segala informasi instansi yang menaunginya. Sebagi mediator humas melaksanakannya sesuai dengan tupoksi humas sebagaiman mestinya. Faktor - 
faktor pendukung dan penghambat daripada aktivitas humas DPRD Kota Palu sebagai mediator yaitu minimnya sumber daya manusia (SDM) pada bagian humas namun diakali dengan pembagian tugas untuk masing-masing staf yang bertujuan untuk memaksimalkan kinerja daripada staf; dan kurangnya fasilitas untuk mendukung aktivitas humas seperti halnya website sebagai salah satu wadah penyebarluasan informasi kepada masyarakat mengenai halhal yang akan atau telah dilakukan oleh anggota dewan yang belum bisa diakses akibat tidak terhubungnya internet.

\section{Referensi}

Alfiyaty, R., Fitri, F., \& Lampe, I. (2021). PENYEBARAN INFORMASI KEPADA STAKEHOLDERS MELALUI PENGELOLAAN CYBER PR TVRI SULAWESI TENGAH (SULTENG). Kinesik, $8(1), 41-52$.

Bungin, B. (2006). Sosiologi Komunikasi: Teori, Paradigma, dan Diskursus. Teknologi Komunikasi di masyarakat. Jakarta: Kencana pernada Media. Group. Jakarta: Kencana Prenada Media Grup.

Effendy, O. U. (2000). Ilmu Komunikasi Teori dan Praktek. Bandung: Remaja Rosda Karya.

Kriyantono, R. (2006). Teknik Praktis Riset Komunikasi. Jakarta: Kencana Perdana.

Nurjannah, \& Sonni, A. F. (2021). Konstruksi Pemberitaan Kepala Daerah di Kota Makassar Terkait COVID-19, 4(01), 17-26.

Ruslan, R. (2008). Manajemen Public Relations dan Media Komunikasi (Edisi : 9). Jakarta: Raja Grafindo Persada.

Scherr, S., \& Baugut, P. (2016). The Meaning of Leaning: The Impact of Journalists' Political Leaning on Active Role Perception and Satisfaction With Audiences and
Editorial Policy. Journalism \& Mass Communication Quarterly, 93(1), 142-163.

https://doi.org/10.1177/10776990156 06678

Sietel, F. P. (1992). The Practice Of Public Relations (Ed.5). New York: Macmillan Publishing Company. Widjaja, H. A. . (2002). Komunikasi : Komunikasi Dan Hubungan Masyarakat. Bumi Aksara (edisi 1). Jakarta: Bumi Aksara.

Yusuf, A. J., \& Sonni, A. F. (2017). PILKADA DALAM PEMBERITAAN DI HARIAN RADAR SELATAN (Analisis Isi Objektivitas Berita Pemilihan Kepala Daerah Kabupaten Bulukumba Di Harian Radar .... KAREBA: Jurnal Ilmu Komunikasi, 5(1). Diambil dari http://journal.unhas.ac.id/index.php/k areba/article/view/1879. 